\title{
Produkcja biokomponentów paliwowych drugiej i trzeciej generacji poprzez procesy termochemiczne - bioolej z mikroalg
}

Rosnące uprzemysłowienie oraz dynamicznie rozwijający się sektor transportowy spowodowały w ostatnich dziesięcioleciach gwałtowny wzrost konsumpcji paliw. Eksploatacja kurczących się zasobów paliw kopalnych przyczynia się do ustawicznego pogarszania środowiska naturalnego, głównie przez obciążenie atmosfery ziemskiej coraz większymi ilościami gazów cieplarnianych, w tym ditlenku węgla $\left(\mathrm{CO}_{2}\right)$. Z tego powodu od ponad dwóch dekad do komponowania paliw ciekłych stosuje się dodatki biopaliwowe. Powszechnie wykorzystywanymi biokomponentami są bioetanol oraz estry metylowe kwasów tłuszczowych (FAME), tzw. biopaliwa pierwszej generacji. Technologie produkcji tych biopaliw bazują głównie na surowcach jadalnych (paszowych), dlatego - biorąc pod uwagę ogromną skalę problemu głodu na całym globie - budzą olbrzymie kontrowersje. Te uwarunkowania stoją u podstaw rozwoju nowych technologii konwersji surowców niejadalnych/odpadowych do biopaliw drugiej generacji (z odpadów lignocelulozowych) oraz biopaliw trzeciej generacji z surowców pochodzących z dedykowanych procesów biologicznych. Przedstawione wyniki badań dotyczą otrzymywania półproduktu biopaliwa trzeciej generacji, tj. biooleju popirolitycznego, pozyskanego z mieszaniny biomasy mikroalg z gatunków Chlorella $s p$. i Scenedesmus $s p$. Na drodze pirolizy uzyskano około 30\% $(\mathrm{m} / \mathrm{m})$ biooleju w odniesieniu do masy surowca. Stwierdzono, iż uzyski poszczególnych grup produktów (bioolej, faza gazowa, karbonizat) są uzależnione od warunków procesu (temperatura, czas reakcji). Analiza jakościowa (GC-MS) dowiodła, że otrzymany bioolej jest złożoną mieszaniną związków o różnych strukturach i właściwościach. Co ciekawe, analiza odporności na utlenianie termooksydacyjne badanego produktu wykazała znacznie lepszą jego stabilność w porównaniu z czystym biodieslem. Badania podstawowych parametrów fizykochemicznych dowodzą, że bioolej pozyskany na drodze pirolizy biomasy mikroalg, poddany odpowiednim procesom rafinacyjnym i uszlachetniającym, może z powodzeniem znaleźć zastosowanie jako biokomponent paliwowy.

Słowa kluczowe: biopaliwa, bioolej, piroliza, mikroalgi.

\section{Production of 2nd and 3rd generation biofuels via thermochemical conversion - bio-oil from microalgae}

The development of industrialization and a dynamically growing transport sector, has caused a sharp increase in fuel consumption over the last decades. The exploitation of the depleting resources of fossil fuels, contributes to the continual degradation of the natural environment, primarily by increasing the amount of greenhouse gases including carbon dioxide in the earth's atmosphere. For this reason, biofuel additives have been used for more than two decades in the blending of liquid fuels. The most commonly used biocomponents are bioethanol and fatty acid methyl esters (FAME), called the 1st generation biofuels. The technologies for their production are based mainly on edible (feed) raw materials. Thus, taking into account the scale of the global problem of hunger, they arouse enormous controversy. These circumstances support the development of new conversion technologies dedicated to the processing of non-edible/waste biomass into 2 nd generation biofuels (from lignocellulosic waste) and 3rd generation biofuels from the dedicated, biological raw materials. The results of present research concern the pyrolysis bio-oil, derived from microalgae biomass (i.e. mixture of Chlorella sp. 
and Scenedesmus sp.). The bio-oil was produced by pyrolysis with ca. $30 \mathrm{wt} . \%$ yield with respect to the mass of the raw material. It was found that the yields of particular product groups (i.e. bio-oil, gas phase, carbonizate) are influenced by the processing parameters (temperature, reaction time). Qualitative analysis (GC-MS) has shown that our bio-oil is a complex mixture of compounds of different structures and properties. Interestingly, the analysis of oxidation resistance exhibited much better thermooxidative stability of the bio-oil, as compared to pure biodiesel. The physico-chemical parameters studies showed, that bio-oil derived from the pyrolysis of microalgae biomass, subjected to the proper refining processes, can be successfully used as a fuel bio-component.

Key words: biofuels, bio-oil, pyrolysis, microalagae.

\section{Wprowadzenie}

Paliwa jako nośniki energii mają istotny wpływ na wszystkie dziedziny działalności człowieka. Zależność społeczeństwa od paliw i energii generowanej dzięki nim jest proporcjonalna do rozwoju cywilizacyjnego. W dobie gwałtownego rozwoju uprzemysłowienia i motoryzacji obserwuje się coraz bardziej dynamiczny trend zwiększania zapotrzebowania na nowe źródła paliw, głównie ciekłych. Generowanie energii poprzez eksploatację paliw kopalnych wpływa jednak na ustawiczną degradację środowiska naturalnego, co wymusza poszukiwania technologii opartych na źródłach odnawialnych. Struktura wykorzystania źródeł energii jest funkcją poziomu rozwoju nowych technologii i zmienia się w szerokich granicach wraz z upływem czasu. Współcześnie kładzie się duży nacisk na zastępowanie paliw konwencjonalnych odnawialnymi źródłami energii, w tym biopaliwami. Dużą uwagę skupia się również na zwiększeniu udziału energii słonecznej i wiatrowej.

Jedną z metod ograniczenia negatywnego wpływu sektora transportowego na stan środowiska naturalnego jest stopniowe zwiększanie udziału dodatków biopaliw do zasilania silników spalinowych. Spalanie biopaliw nie wnosi dodatkowego udziału ditlenku węgla w atmosferze ziemskiej. Biorąc pod uwagę dynamikę wyczerpywania się światowych zasobów paliw kopalnych, biopaliwa stają się konieczną alternatywą. Biopaliwa na rynku europejskim zostały wprowadzone w latach 90. XX wieku i od tego czasu ich obligatoryjny udział, regulowany odpowiednimi dyrektywami, jest systematycznie zwiększany (rysunek 1). Dodatkami powszechnie stosowanymi jako biokomponenty są bioetanol oraz biodiesel. Wspomniane produkty stanowią jednak biopaliwa pierwszej generacji, których produkcja wywołuje spore kontrowersje ze względu na negatywny wpływ na rynek produktów spożywczych.

Szacuje się, że jeśli rynek biopaliw byłby oparty jedynie na biokomponentach pierwszej generacji, wypełnienie założonego celu 10-procentowego udziału biopaliw w sektorze transportowym w krajach UE-28 wymagałoby wykorzystania areału ponad $21 \mathrm{mln}$ ha gruntów rolnych, co stanowi aż $21 \%$ ogólnej powierzchni dostępnych terenów [17]. Dodat-

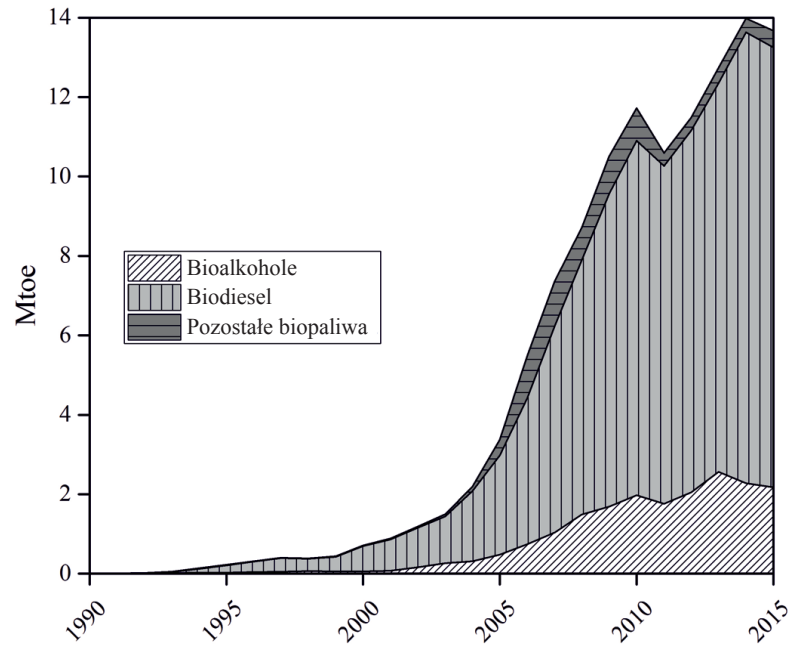

Rys. 1. Zużycie biopaliw w UE-28 w latach 1990-2015 [14]

kowo wiązałoby się to z ogromnym zapotrzebowaniem na wodę oraz nawozy. $\mathrm{Z}$ tego powodu zwiększanie produkcji biopaliw pierwszej generacji jest niemożliwe ze względu na zagrożenia związane z niebezpiecznym wpływem na światowe zasoby gruntów rolnych, żywności oraz wody do ich produkcji. Niezbędny jest zatem rozwój technologii konwersji i przemysłowa implementacja produkcji biopaliw wyższych generacji, dla których bazą surowcową jest biomasa niejadalna lub odpadowa.

Podział biopaliw na poszczególne generacje opiera się głównie na typie przetwarzanego surowca [17]. Biopaliwa drugiej generacji wytwarzane są z biomasy lignocelulozowej, pochodzącej z niejadalnych surowców (traw lub odpadów lignocelulozowych) lub niejadalnych części roślin uprawnych (np. słoma, łupiny). Biopaliwa trzeciej generacji to produkty otrzymywane w wyniku konwersji nowych, przeznaczonych do tego celu surowców (np. algi o wysokiej zawartości lipidów do produkcji biodiesla).

Dodatkowo oprócz aspektu środowiskowego należy podkreślić fakt, że koszt końcowy biopaliwa zależy w decydującym stopniu od ceny surowca, która stanowi szacunkowo $60 \div 75 \%$ całkowitego kosztu wytworzenia paliwa [4]. W związku z tym biopaliwo powinno być produkowane z możliwie najtańszego surowca (np. różnorodne odpady 
organiczne) lub surowca wysokowydajnego w uprawie (np. algi). Mikroalgi sa niezwykle interesującym surowcem do produkcji biopaliw ciekłych, ze względu na wysoką zdolność produkcyjną połączoną z możliwością uprawy na nieużytkach, w słonych lub odpadowych wodach i w zmiennych warunkach klimatycznych, a także brak negatywnego wpły- wu na rynek produktów spożywczych i pasz $[8,13]$. Niskie koszty i wysokowydajna produkcja tego typu surowców oraz korzyści środowiskowe płynące $\mathrm{z}$ ich zastosowania powinny zrównoważyć wysokie koszty kapitałowe komercyjnego wdrożenia technologii pozwalających na konwersję do biopaliw wyższych generacji oraz cennych chemikaliów [11].

\section{Procesy konwersji z uwzględnieniem procesów termochemicznych}

Technologie przetwarzania biomasy można zasadniczo podzielić na trzy grupy:

1) procesy termochemiczne,

2) procesy biochemiczne,

3) procesy chemiczne.

Schemat systematyzujący badane i wdrażane technologie procesów przetwarzania biomasy w kierunku pozyskiwania różnorodnych bioproduktów przedstawiono na rysunku 2 .

Biomasa może być wykorzystywana do produkcji różnych typów nośników energii, m.in. biooleju, biodiesla, gazu syntezowego, bioetanolu czy biowodoru. Konwersja biochemiczna jest rozważana głównie pod kątem produkcji lekkich cząsteczek, takich jak: metan, etanol czy wodór. Przetwarzanie materii organicznej na drodze konwersji chemicznej opiera się głównie na ekstrakcji wartościowych składników wchodzących w skład biomasy, a wśród nich przede wszystkim lipidów, a następnie ich przetworzeniu do postaci biodiesla poprzez reakcję transestryfikacji lub metody bardziej zaawansowanej technologicznie, jak hydrotreating czy transestryfikacja in-situ.
Obecnie spośród metod konwersji szczególnym zainteresowaniem badaczy cieszą się procesy termochemicznej konwersji. Atrakcyjność tych technologii wynika z możliwości przetwarzania wszystkich frakcji budulcowych materii organicznej. Warunki procesów termochemicznych w dużym stopniu uzależnione są od zawartości wody, stąd procesy te dzieli się na „suche” oraz „mokre”. Czynnikami determinującymi wybór metody przetwarzania biomasy są między innymi dostępne ilości i typ biomasy, oczekiwana postać energii produktu oraz względy ekonomiczne i projektowe.

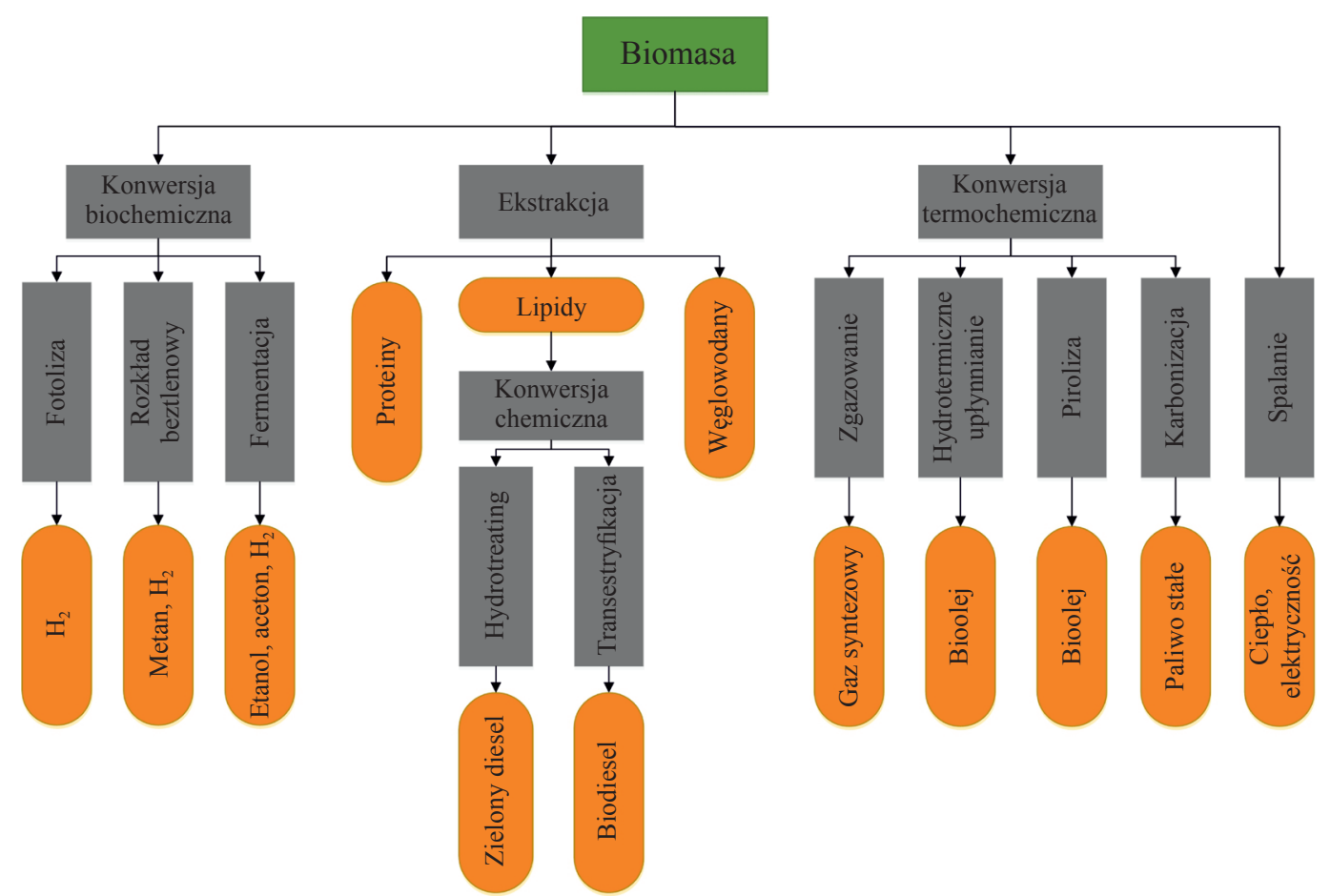

Rys. 2. Podział procesów konwersji biomasy [1]

\section{Bioolej pozyskiwany z biomasy poprzez termochemiczną konwersję}

Uzyskany poprzez termochemiczną konwersję bioolej to w większości przypadków lepka ciecz o ciemnej barwie, którą można porównać z ciężką frakcją ropy naftowej. Wśród związków dotychczas zidentyfikowanych w biooleju można wymienić następujące grupy:

- jednopierścieniowe związki aromatyczne oraz heterocykliczne (m.in. benzen, toluen oraz fenol),
- związki alifatyczne (m.in. alkany, alkeny oraz ich pochodne),

- związki tlenowe (m.in. kwasy karboksylowe o długich łańcuchach, estry, aldehydy, ketony),

- związki azotowe (m.in. aminy, amidy, nitryle),

- wielopierścieniowe węglowodory aromatyczne (WWA) (m.in. naftalen, inden oraz ich pochodne) [10]. 
Udziały poszczególnych grup oraz właściwości fizykochemiczne uzależnione są od rodzaju surowca oraz parametrów procesowych. Bez wątpienia głównym mankamentem pozyskiwanych bioolejów jest duża zawartość związków tlenowych i azotowych. Wartość opałowa biooleju z biomasy najczęściej mieści się w granicach $25 \div 35 \mathrm{MJ} / \mathrm{kg}$, jest zatem znacznie większa od wartości opałowej surowej biomasy. Wartość energetyczna biooleju stanowi przeciętnie $70 \div 95 \%$ wartości dla ropy naftowej [3]. W porównaniu $\mathrm{z}$ biomasą stałą bioolej jest paliwem łatwiejszym w magazynowaniu oraz transporcie. Dzięki swojemu składowi oraz właściwościom fizykochemicznym daje szerokie spektrum możliwych dalszych aplikacji, m.in. jako:

- paliwo transportowe i dobry substytut paliw kopalnych (po odpowiednich procesach uszlachetniających),
- źródło ciepła lub energii elektrycznej,

- półprodukt do wytwarzania rozmaitych chemikaliów i żywic,

- środek konserwujący (np. do impregnacji drewna), środek wiążący do peletyzacji i brykietowania palnych odpadów organicznych lub do produkcji klejów.

W oparciu o dane literaturowe można stwierdzić istnienie dużego zróżnicowania w odniesieniu do uzysków biooleju, nawet w przypadku przetwarzania tego samego rodzaju biomasy w identycznych warunkach konwersji.

Celem niniejszego artykułu jest przedstawienie zarysu zagadnień związanych z produkcją biopaliw drugiej i trzeciej generacji oraz omówienie możliwości produkcji popirolitycznego biooleju trzeciej generacji z biomasy mikroalg.

\section{Metodyka badań}

Materiałem badawczym była mieszanina mikroalg z gatunków Chlorella sp. i Scenedesmus sp., uprawiana w warunkach autotroficznych w otwartych akwenach. Pirolizę suchego materiału badawczego przeprowadzono w układzie reakcyjnym, wyposażonym w reaktor ze złożem stałym. Szczegółowe informacje dotyczące materiału badawczego oraz układu reakcyjnego publikowano wcześniej [19]. Proces pirolizy zrealizowano w różnych warunkach zdefiniowanych:

- temperaturą $350 \div 550^{\circ} \mathrm{C}$,

- czasem reakcji 5 $\div 30 \mathrm{~min}$,

- dodatkowym mieleniem surowej biomasy.

Separację produktów konwersji przeprowadzono poprzez ekstrakcję dichlorometanem (Avantor P.M.P., 99,5\% CZDA).

\section{Badania termograwimetryczne surowca (TGA/DTG)}

Termiczny rozkład materii organicznej mikroalg badano przy wykorzystaniu termowagi ciśnieniowej firmy Rubotherm. Masa materiału badawczego poddawanego analizie wynosiła około $400 \mathrm{mg}$, szybkość narostu temperatury $20^{\circ} \mathrm{C} / \mathrm{min}$. Analizę prowadzono w strumieniu gazu inertnego (Ar - czystość 5,0; $100 \mathrm{ml} / \mathrm{min})$.

\section{Chromatografia gazowa - spektrometria mas (GC-MS)}

Badania wykonano przy użyciu chromatografu gazowego Agilent 7890B, wyposażonego w kolumnę kapilarną Agilent DB-17 $(30 \mathrm{~m} \times 250 \mu \mathrm{m}$ ID $\times 0,25 \mu \mathrm{m})$, sprzężonego ze spektrometrem masowym MS-5977A. Próbki do analiz GC-MS przygotowano jako $5 \%(\mathrm{~m} / \mathrm{m})$ roztwory w acetonie (Sigma Aldrich, odczynnik do HPLC). Przed dozowaniem do chromatografu próbki filtrowano (filtry PTFE $0,2 \mu \mathrm{m}$ ). W analizie GC-MS zidentyfikowano maksymalnie 100 związków, interpretując jedynie piki o dużym stopniu zgodności (powyżej 75\%) z biblioteką widm MS (NIST 1A v17). Rozpo- znane związki podzielono według obecnych w ich strukturach grup funkcyjnych oraz dominującego charakteru na jedenaście zbiorów:

1) aminy,

2) amidy,

3) nitryle,

4) związki cykliczne (laktamy, laktony, cykliczne iminy i imidy oraz węglowodory cykliczne),

5) węglowodory alifatyczne (alkany, alkeny oraz ich pochodne),

6) związki aromatyczne (węglowodory aromatyczne, związki heterocykliczne o charakterze aromatycznym),

7) indol i jego pochodne,

8) fenol i jego pochodne,

9) ketony,

10) estry, alkohole i kwasy karboksylowe,

11) pozostałe związki (charakteryzujące się obecnością wielu grup funkcyjnych).

\section{Analiza właściwości fizykochemicznych}

1. Zawartość wody w biooleju oraz w fazie wodnej oznaczono metodą miareczkowania kulometrycznego (aparat Karl-Fischer Moisture Titrator MKC-501, Kyoto Electronics) według normy PN-EN 15489:2009.

2. Temperaturę zapłonu w tyglu zamkniętym określono (aparat Eraflash, Eralytics) według normy ASTM D93A.

3. Liczbę kwasową ustalono metodą miareczkowania potencjometrycznego według normy PN-ISO 6619:2011.

4. Lepkość kinematyczną oznaczono za pomocą lepkościomierza Stabingera (aparat SVM 3000, Anton Parr) według normy PN-C-04357:2009.

5. Gęstość bezwzględną określono metodą piknometryczną według normy PN-EN ISO 3838:2008. 
6. Stabilność oksydacyjną ustalono metodą przyspieszonego utleniania w temperaturze $140^{\circ} \mathrm{C}$ w obecności tlenu (aparat PetroOxy, Petrotest) według normy EN 16091.

\section{Uzyski produktów}

Uzyski poszczególnych grup produktów obliczono według zależności przedstawionej równaniem (1) - jako stosunek masy poszczególnych produktów do masy materiału badawczego, w przeliczeniu na stan suchy i bezpopiołowy.

$$
U_{i}=\frac{m_{i, d a f}}{m_{a \mid \mathrm{g} i, d a f}} \cdot 100
$$

gdzie:

$U_{i}$ - uzysk odpowiednio: biooleju, fazy wodnej, gazu i sta-

łej pozostałości [\% $(\mathrm{m} / \mathrm{m})]$,

$m_{i, d a f}$ - masa biooleju, fazy wodnej, gazu i stałej pozostało-

ści w stanie suchym i bezpopiołowym,

$m_{\text {algi,daf }}$ - masa surowca w stanie suchym i bezpopiołowym.

\section{Wyniki badań i dyskusja}

Analiza termograwimetryczna materiału badawczego została przeprowadzona w przedziale temperatur $50 \div 900^{\circ} \mathrm{C}$ w celu określenia przybliżonych zakresów temperaturowych rozkładu składników budulcowych biomasy mikroalg (rysunek 3).

Podczas rozkładu pirolitycznego badanych mikroalg w atmosferze inertnej wyróżnić można trzy zasadnicze etapy utraty masy, które przypisuje się:

- dehydratacji, która zachodzi w zakresie temperatur od około $50^{\circ} \mathrm{C}$ do $200^{\circ} \mathrm{C}$ (rysunek 3, I);

- rozkładowi/depolimeryzacji materii organicznej (proteiny, węglowodany i lipidy), obserwowanemu w prze-

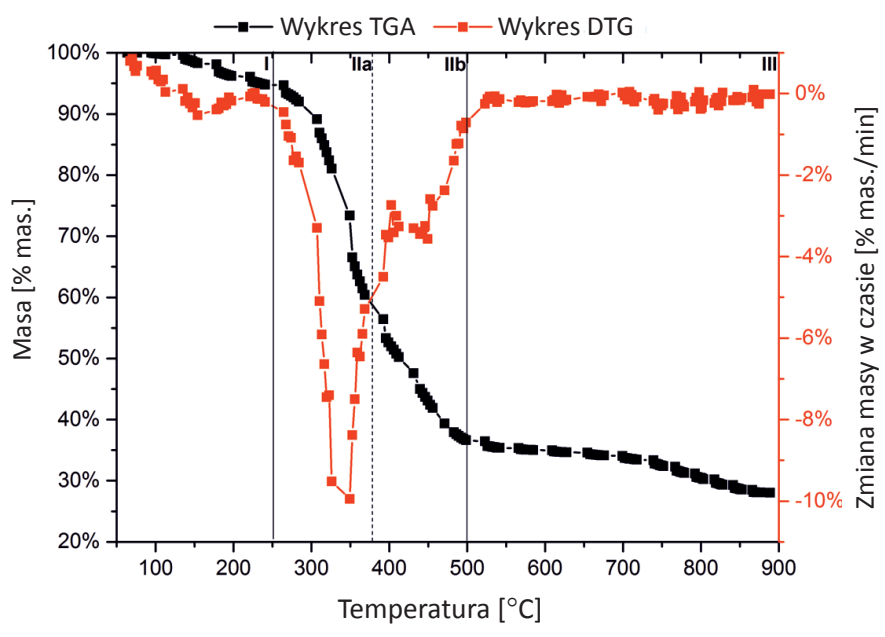

Rys. 3. Wyniki badań termograwimetrycznych TGA/DTG przedmiotowych mikroalg

dziale temperatur od 250 do $550^{\circ} \mathrm{C}$ (rysunek 3, IIa, IIb). $\mathrm{W}$ tym etapie zarejestrowano największy ubytek masy (około $60 \%(\mathrm{~m} / \mathrm{m})$ ). W zakresie temperatur od 250 do $390^{\circ} \mathrm{C}$ (rysunek 3, IIa) następował drastyczny ubytek masy, tj. $43 \%(\mathrm{~m} / \mathrm{m})$. Efekt ten przypisuje się rozkładowi protein oraz węglowodanów. Największą dynamikę utraty masy (wartość minimalna na krzywej DTG) osiągnięto $\mathrm{w}$ temperaturze $349^{\circ} \mathrm{C}$. W wyższym przedziale temperatur, tj. $390 \div 550^{\circ} \mathrm{C}$ (rysunek 3, IIb), zaobserwowano nieco mniejszą utratę masy (około $18 \%(\mathrm{~m} / \mathrm{m})$ ). W tym etapie następuje rozkład lipidów i składników ścian komórkowych;

- rozkładowi substancji węglowych zawartych w stałej pozostałości, obserwowanemu w zakresie temperatur $550 \div 900^{\circ} \mathrm{C}$ (rysunek 3 , III). Podczas tego etapu zaobserwowano niewielki ubytek masy [9].

\section{Wpływ warunków procesu pirolizy na zmianę uzysków grup produktów}

Temperatura procesu pirolizy jest parametrem istotnie wpływającym na zmianę uzysków produktów (rysunek 4a). Uzysk biooleju stopniowo wzrastał z podwyższeniem temperatury, aż do osiągnięcia wartości maksymalnej (tj. $32,75 \%(\mathrm{~m} / \mathrm{m}))$ w temperaturze pirolizy $450^{\circ} \mathrm{C}$. Intensywniejsze formowanie biooleju było związane z postępującą konwersją protein, węglowodanów oraz lipidów. Temperatura procesu pirolizy powyżej $450^{\circ} \mathrm{C}$ prowadziła do obniżenia uzysku biooleju, co przypisano wtórnym reakcjom krakingu par oleju w kierunku niekondensujących produktów gazowych oraz reformingowi lekkich frakcji biooleju, a także zgazowaniu. Trend ten potwierdzają badania własne, w czasie których zaobserwowano wzrost udziału produktów gazowych z podwyższeniem temperatury. Obserwacje te są zgodne z wcześniej publikowanymi wynikami $[6,20]$.
Relatywnie duża ilość stałych pozostałości otrzymanych po procesie pirolizy w temperaturze $350^{\circ} \mathrm{C}$ jest zgodna $\mathrm{z}$ wynikami uzyskanymi podczas TGA i świadczy o płytkim rozkładzie badanych mikroalg w tych warunkach. Badania procesu w zakresie temperatury $450 \div 550^{\circ} \mathrm{C}$ wykazały, że zawartość stałych pozostałości kształtowała się na poziomie $30 \div 33 \%(\mathrm{~m} / \mathrm{m})$, co jest bliskie całkowitej ilości węgla związanego oraz popiołu. Można zatem sformułować wniosek, iż temperatura $450^{\circ} \mathrm{C}$ i odpowiedni dobór czasu reakcji są wystarczające do rozkładu większości składników organicznych biomasy badanych gatunków mikroalg. W wyższych temperaturach $\left(>500^{\circ} \mathrm{C}\right)$ zachodzi kraking termiczny, co prowadzi do intensywniejszego formowania związków o niższych masach cząsteczkowych i produktów gazowych. Proteiny, lipidy i węglowodany rozkładają się w niższych temperaturach 
a)

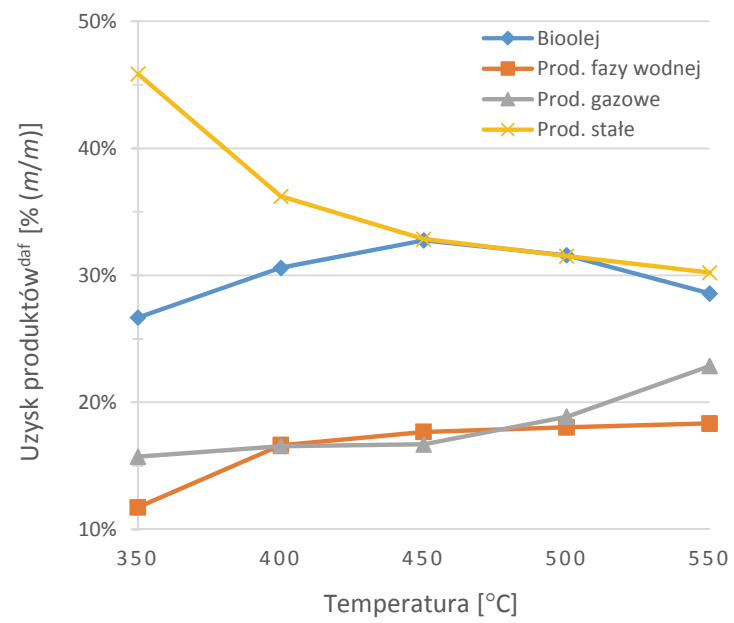

b)

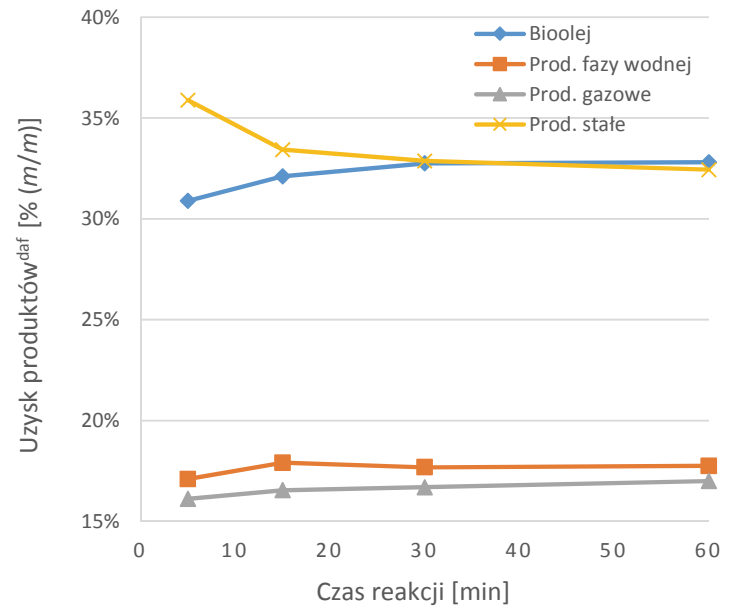

Rys. 4. Wpływ warunków procesu pirolizy na zmianę udziału poszczególnych grup produktów:

a) temperatura (dla czasu reakcji $30 \mathrm{~min}, \mathrm{~b}$ ) czas reakcji (dla temperatury procesu $450^{\circ} \mathrm{C}$ )

niż lignoceluloza [7, 12], dlatego też optymalna temperatura formowania biooleju z biomasy mikroalg jest zawsze niższa niż w przypadku biomasy lignocelulozowej (tj. około $550 \div 600^{\circ} \mathrm{C}$ ).

Wpływ czasu reakcji na uzyski produktów procesu pirolizy przedstawiono na rysunku $4 \mathrm{~b}$. W porównaniu $\mathrm{z}$ temperaturą czas reakcji miał mniejszy wpływ na kształt udziałów poszczególnych produktów konwersji. Uzysk frakcji biooleju w temperaturze $450^{\circ} \mathrm{C}$ zmieniał się z 30,9 do $32,9 \%(\mathrm{~m} / \mathrm{m})$ $\mathrm{w}$ odniesieniu do masy surowca przy zmianie czasu z 5 do 60 minut. Niewielka zmiana uzysku biooleju przy dłuższych czasach reakcji mogła być związana z konwersją stałej pozostałości materiału organicznego, np. najstabilniejszych ter- micznie molekuł. Ponadto dłuższe czasy reakcji powodowały nieznaczne zwiększenie uzysku gazu w wyniku wtórnych reakcji biooleju oraz zmniejszenie uzysku stałej pozostałości. Podsumowując, można stwierdzić, że długie czasy reakcji nie powodowały znacznych zmian udziałów produktów, a wiązały się z dodatkowymi kosztami energetycznymi.

Badano również wpływ dodatkowego rozdrobnienia ziaren biomasy na strukturę uzysków poszczególnych grup produktów, jednak nie zaobserwowano istotnego wpływu tego parametru. W przypadku mikroalg rozmiar komórek był wystarczająco mały do przeprowadzenia pełnego odgazowania, zatem stosowanie dodatkowych procesów nie znajduje uzasadnienia ekonomicznego.

\section{Analiza składu oraz właściwości fizykochemicznych biooleju}

Uzyskane biooleje popirolityczne są złożoną mieszaniną zawierającą ogromną liczbę związków o bardzo szerokim zakresie mas cząsteczkowych. Skład jakościowy analizowano za pomocą chromatografii gazowej sprzężonej ze spektrometrią mas (GC-MS), dzięki której scharakteryzowano lekką frakcję o temperaturze wrzenia poniżej $350^{\circ} \mathrm{C}$. Główne grupy związków to wyższe alkany, alkeny, związki heterocykliczne zarówno o układach aromatycznych, jak i alicyklicznych, aminy, indywidua o charakterze fenolowym i indolowym oraz amidy. Wpływ temperatury procesu pirolizy na zmianę składu grupowego frakcji olejowej przedstawiono na rysunku 5 . Wzrost temperatury procesu pirolizy powodował wyraźną zmianę struktury udziałów poszczególnych grup związków w biooleju. W olejach popirolitycznych stwierdzono relatywnie wysoką zawartość węglowodorów alifatycznych, których udział kształtował się w zakresie $17,9 \div 19,8 \%(\mathrm{~m} / \mathrm{m})$. Niewielki spadek udziału tej grupy przy wzroście temperatury był spowodo- wany ich wtórną aromatyzacją lub cyklizacją w temperaturach około $500 \div 550^{\circ} \mathrm{C}$. To przypuszczenie znajduje potwierdzenie w nieznacznym wzroście uzysku węglowodorów aromatycznych. Przy wyższej o $100^{\circ} \mathrm{C}$ temperaturze konwersji zaobserwowano spadek udziału grupy związków złożonych z $8,1 \%$ do $1,6 \%(\mathrm{~m} / \mathrm{m})$, co jest wynikiem głębszego krakingu termicznego trwalszych połączeń. Stwierdzono również spadek koncentracji nitryli kosztem wzrostu ilości amin oraz amidów, co można przypisać procesom hydrolizy nitryli do kwasów karboksylowych oraz redukcji do amin pierwszorzędowych. Biorąc pod uwagę obecność w olejach popirolitycznych związków zawierających aktywne grupy aldehydowe, należy również uwzględnić możliwość zachodzenia reakcji polikondensacji i tworzenia wielkocząsteczkowych żywic fenolowych. Tego typu makromolekuły w wyższych temperaturach ulegają stopniowej kondensacji, połączonej z utratą pierwiastków niewęglowych i tworzeniem karbonizatów. 
Tablica 1. Udziały wybranych składników biooleju w zależności od temperatury procesu pirolizy [18]

\begin{tabular}{|c|c|c|c|c|c|}
\hline \multirow{2}{*}{ Grupa } & \multirow{2}{*}{$\begin{array}{c}\mathrm{RT} \\
{[\mathrm{min}]}\end{array}$} & \multirow{2}{*}{ Nazwa związku } & \multirow{2}{*}{ Wzór } & \multicolumn{2}{|c|}{$\begin{array}{c}\text { Udział procentowy } \\
\text { pow. pików GC [\% pow.] }\end{array}$} \\
\hline & & & & $\begin{array}{l}\text { temperatura } \\
450^{\circ} \mathrm{C}\end{array}$ & $\begin{array}{l}\text { temperatura } \\
550^{\circ} \mathrm{C}\end{array}$ \\
\hline \multirow{3}{*}{ Amidy } & 33,8 & Heksanoamid & $\mathrm{C}_{6} \mathrm{H}_{13} \mathrm{NO}$ & - & 0,39 \\
\hline & 71,1 & Heksadekanoamid & $\mathrm{C}_{16} \mathrm{H}_{33} \mathrm{NO}$ & 1,76 & 2,41 \\
\hline & 76,2 & 9-Oktadekanoamid & $\mathrm{C}_{18} \mathrm{H}_{35} \mathrm{NO}$ & 0,76 & 1,31 \\
\hline \multirow{7}{*}{ Nitryle } & 5,5 & Propanonitryl & $\mathrm{C}_{3} \mathrm{H}_{5} \mathrm{~N}$ & 0,23 & 0,30 \\
\hline & 8,1 & Pentanonitryl & $\mathrm{C}_{5} \mathrm{H}_{9} \mathrm{~N}$ & - & 0,18 \\
\hline & 15,7 & 4-metylopentanonitryl & $\mathrm{C}_{6} \mathrm{H}_{11} \mathrm{~N}$ & 0,94 & 0,79 \\
\hline & 33,0 & Benzylonitryl & $\mathrm{C}_{8} \mathrm{H}_{7} \mathrm{~N}$ & 0,41 & 0,31 \\
\hline & 38,2 & Benzenopropanonitryl & $\mathrm{C}_{9} \mathrm{H}_{9} \mathrm{~N}$ & 1,13 & 0,90 \\
\hline & 60,4 & Pentadekanonitryl & $\mathrm{C}_{15} \mathrm{H}_{29} \mathrm{~N}$ & 3,60 & 2,38 \\
\hline & 66,3 & Oleanitryl & $\mathrm{C}_{18} \mathrm{H}_{33} \mathrm{~N}$ & 1,94 & 1,30 \\
\hline \multirow{3}{*}{ Związki cykliczne } & 29,6 & 2,2,6,6-tetrametylo-4-piperydynon & $\mathrm{C}_{9} \mathrm{H}_{17} \mathrm{NO}$ & 3,46 & 6,44 \\
\hline & 40,5 & Metylocyklodekan & $\mathrm{C}_{11} \mathrm{H}_{22}$ & - & 0,73 \\
\hline & 53,6 & 2,6,6-trimetylo-bicyklo[3,1,1]heptan & $\mathrm{C}_{10} \mathrm{H}_{18}$ & 3,67 & 4,23 \\
\hline \multirow{11}{*}{$\begin{array}{l}\text { Węglowodory } \\
\text { alifatyczne }\end{array}$} & 7,9 & Oktan & $\mathrm{C}_{8} \mathrm{H}_{18}$ & - & 0,19 \\
\hline & 7,9 & Okt-1-en & $\mathrm{C}_{8} \mathrm{H}_{16}$ & - & 0,15 \\
\hline & 12,0 & Nonan & $\mathrm{C}_{9} \mathrm{H}_{20}$ & 0,30 & 0,31 \\
\hline & 12,1 & Non-1-en & $\mathrm{C}_{9} \mathrm{H}_{18}$ & - & 0,24 \\
\hline & 16,9 & Dekan & $\mathrm{C}_{10} \mathrm{H}_{22}$ & 0,43 & 0,39 \\
\hline & 22,0 & Undekan & $\mathrm{C}_{11} \mathrm{H}_{24}$ & 0,70 & 0,67 \\
\hline & 27,0 & Dodekan & $\mathrm{C}_{12} \mathrm{H}_{26}$ & 0,74 & 0,61 \\
\hline & 36,1 & Tetradekan & $\mathrm{C}_{14} \mathrm{H}_{30}$ & 1,45 & 1,15 \\
\hline & 40,4 & Pentadekan & $\mathrm{C}_{15} \mathrm{H}_{32}$ & 3,18 & 2,23 \\
\hline & 48,1 & Heptadekan & $\mathrm{C}_{17} \mathrm{H}_{36}$ & 2,03 & 1,66 \\
\hline & 75,5 & Eikozan & $\mathrm{C}_{20} \mathrm{H}_{42}$ & 0,86 & - \\
\hline \multirow{8}{*}{ Związki aromatyczne } & 5,6 & Benzen & $\mathrm{C}_{6} \mathrm{H}_{6}$ & - & 0,19 \\
\hline & 9,6 & Toluen & $\mathrm{C}_{7} \mathrm{H}_{8}$ & 2,03 & 2,46 \\
\hline & 12,5 & Pirol & $\mathrm{C}_{4} \mathrm{H}_{5} \mathrm{~N}$ & 1,45 & 1,36 \\
\hline & 14,0 & p-Ksylen & $\mathrm{C}_{8} \mathrm{H}_{10}$ & 0,19 & 0,46 \\
\hline & 14,1 & m-Ksylen & $\mathrm{C}_{8} \mathrm{H}_{10}$ & - & 0,65 \\
\hline & 16,1 & Styren & $\mathrm{C}_{8} \mathrm{H}_{8}$ & 0,46 & 0,54 \\
\hline & 17,1 & Propylobenzen & $\mathrm{C}_{9} \mathrm{H}_{12}$ & 0,30 & 0,33 \\
\hline & 26,2 & Trimetylopirazyna & $\mathrm{C}_{7} \mathrm{H}_{10} \mathrm{~N}_{2}$ & - & 1,15 \\
\hline \multirow{2}{*}{ Indol } & 41,9 & Indol & $\mathrm{C}_{8} \mathrm{H}_{7} \mathrm{~N}$ & 3,42 & 2,64 \\
\hline & 45,0 & 3-metylo-1H-Indol & $\mathrm{C}_{9} \mathrm{H}_{9} \mathrm{~N}$ & 0,84 & 0,87 \\
\hline \multirow{4}{*}{ Fenole } & 29,8 & Fenol & $\mathrm{C}_{6} \mathrm{H}_{6} \mathrm{O}$ & 2,15 & 1,94 \\
\hline & 32,3 & o-Krezol & $\mathrm{C}_{7} \mathrm{H}_{8} \mathrm{O}$ & 0,71 & 0,65 \\
\hline & 34,1 & p-Krezol & $\mathrm{C}_{7} \mathrm{H}_{8} \mathrm{O}$ & 2,49 & 2,23 \\
\hline & 37,3 & 4-etylofenol & $\mathrm{C}_{8} \mathrm{H}_{10} \mathrm{O}$ & 0,33 & 0,37 \\
\hline \multirow{3}{*}{ Ketony } & 9,6 & Heks-5-en-2-on & $\mathrm{C}_{6} \mathrm{H}_{10} \mathrm{O}$ & 0,34 & 0,50 \\
\hline & 17,5 & Alkohol diacetonowy & $\mathrm{C}_{6} \mathrm{H}_{12} \mathrm{O}_{2}$ & 2,35 & 3,49 \\
\hline & 56,5 & Dodekan-2-on & $\mathrm{C}_{12} \mathrm{H}_{24} \mathrm{O}$ & 0,38 & 0,26 \\
\hline \multirow{3}{*}{ Estry } & 58,4 & Ester metylowy kwasu hekadekanowego & $\mathrm{C}_{17} \mathrm{H}_{34} \mathrm{O}_{2}$ & 0,39 & 0,33 \\
\hline & 73,5 & Bis(2-etyloheksylo) ester kwasu heksanodiowego & $\mathrm{C}_{22} \mathrm{H}_{42} \mathrm{O}_{4}$ & 6,09 & 4,39 \\
\hline & 78,1 & $\begin{array}{l}\text { Mono(2-etyloheksylo) ester kwasu benzeno-1,2- } \\
\text { dikarboksylowego }\end{array}$ & $\mathrm{C}_{16} \mathrm{H}_{22} \mathrm{O}_{4}$ & 18,43 & 12,39 \\
\hline
\end{tabular}



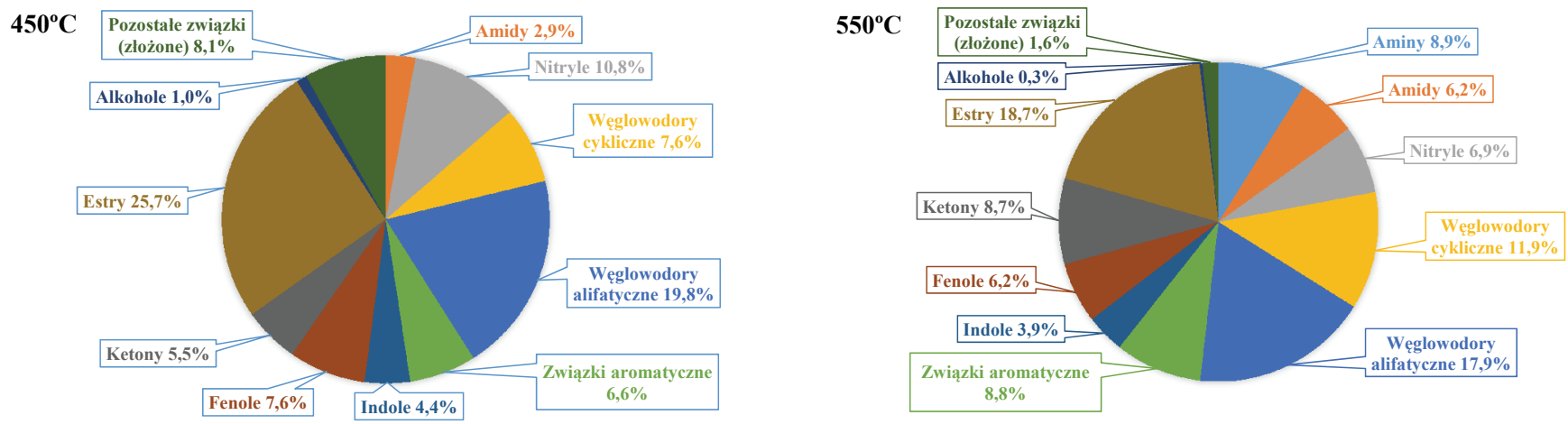

*Udziały procentowe określone jako stosunek powierzchni pików grupy związków do powierzchni wszystkich zidentyfikowanych pików

Rys. 5. Skład grupowy bioolejów popirolitycznych uzyskanych w 450 i $550^{\circ} \mathrm{C}$ [18]

W tablicy 1 przedstawiono wybrane związki zidentyfikowane w biooleju popirolitycznym. W uzyskanym biooleju stwierdzono obecność alkanów i alkenów o liczbie atomów węgla w cząsteczce w zakresie $\mathrm{C}_{8}-\mathrm{C}_{12}$. Te związki mogą być stosowane m.in. do komponowania benzyn silnikowych. Wśród zidentyfikowanych związków aromatycznych dominują połączenia węglowodorowe, a niewielki udział mają związki heterocykliczne o charakterze aromatycznym (pirol). Relatywnie duży udział stanowią estry o rozbudowanych strukturach i liczbie atomów węgla $\mathrm{C}_{16}-\mathrm{C}_{22}$. Wśród ketonów dominują związki łańcuchowe.

Zbadano również podstawowe parametry fizykochemiczne otrzymanych bioolejów i porównano z charakterystyką oleju napędowego oraz popirolitycznego biooleju uzyskanego $\mathrm{z}$ drewna. Dane przedstawiono w tablicy 2.

Biooleje uzyskane $\mathrm{z}$ biomasy mikroalg charakteryzowały się niższą gęstością od bioolejów otrzymanych z biomasy lignocelulozowej, a wyższą od oleju napędowego. Lepkość kształtowała się w typowym zakresie dla biooleju z biomasy lignocelulozowej $[2,16]$. Obecność w biooleju z mikroalg związków azotowych (indole, pirydyna, aminy czy amoniak) przekłada się na odczyn alkaliczny $(\mathrm{pH}=9,2 \div 9,5)$, co jest różne od wartości pH bioolejów uzyskanych z biomasy lignocelulozowej (na ogół $\mathrm{pH}=2 \div 3$ ) [16]. Podobne rezultaty w odniesieniu do $\mathrm{pH}$ bioolejów uzyskanych z mikroalg opisywali również inni badacze [5, 8]. Zawartość substancji mineralnej w biooleju otrzymanym z mikroalg była niewielka $(<0,5 \%(m / m))$.

Uzyskany w badaniach własnych bioolej popirolityczny charakteryzował się lepszą o ponad 37\% stabilnością

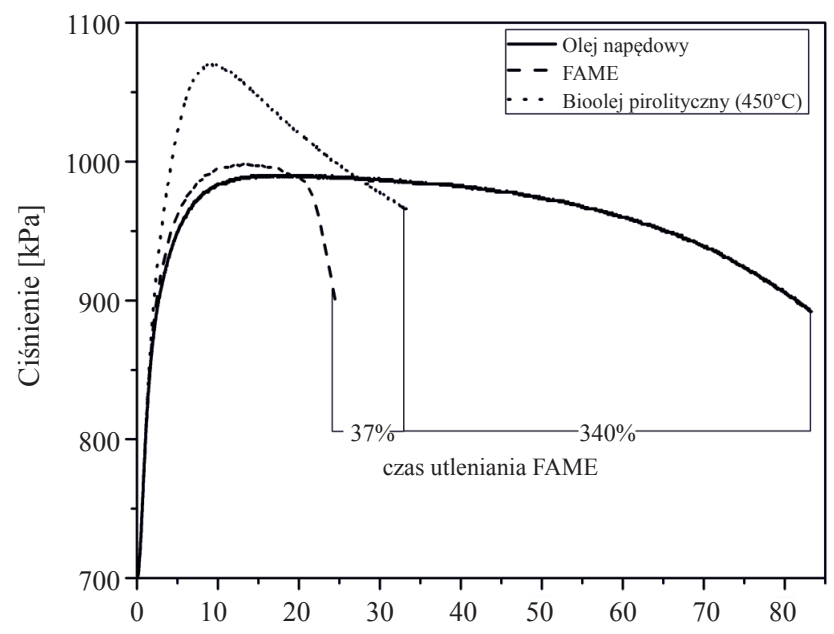

Rys. 6. Stabilność termooksydacyjna biooleju popirolitycznego, FAME i ON

Tablica 2. Właściwości fizykochemiczne biooleju z badań własnych w porównaniu z parametrami innych paliw ciekłych [18]

\begin{tabular}{|l|c|c|c|}
\hline \multicolumn{1}{|c|}{ Parametr } & $\begin{array}{c}\text { Bioolej popirolityczny } \\
\text { z biomasy mikroalga }\end{array}$ & $\begin{array}{c}\text { Bioolej popirolityczny } \\
\text { z biomasy lignocelulozowej }{ }^{\mathrm{b}}\end{array}$ & Olej napędowy $^{\mathrm{c}}$ \\
\hline Gęstość $\left[\mathrm{kg} / \mathrm{dm}^{3}\right]$ & 1,01 & 1,20 & $0,82 \div 0,85$ \\
\hline Lepkość kinematyczna w $40^{\circ} \mathrm{C}\left[\mathrm{mm}^{2} / \mathrm{s}\right]$ & 56,8 & $25 \div 1000$ & $2,5 \div 3,2$ \\
\hline Temperatura zapłonu $\left[{ }^{\circ} \mathrm{C}\right]$ & 126 & b.d. & $>56$ \\
\hline Liczba kwasowa $[\mathrm{mg} \mathrm{KOH} / \mathrm{g}$ próbki] & 116,9 & b.d. & b.d. \\
\hline Zawartość wody $[\mathrm{mg} / \mathrm{g}]$ & 598 & $150 \div 300$ & $<200$ \\
\hline Wartość opałowa $[\mathrm{MJ} / \mathrm{kg}]$ & $27 \div 29$ & $16 \div 19$ & 43 \\
\hline pH & 9,2 & $2 \div 3$ & b.d. \\
\hline Zawartość popiołu $[\%(\mathrm{~m} / \mathrm{m})]$ & $<0,5$ & $\sim 1$ & b.d. \\
\hline
\end{tabular}

${ }^{\mathrm{a}}$ Badania własne, bioolej uzyskany w $450^{\circ} \mathrm{C}, 30 \mathrm{~min}$; ${ }^{\mathrm{b}}$ dane zaczerpnięte $[2,16]$; ${ }^{\mathrm{c}}$ dane zaczerpnięte [15]; b.d. - brak danych. 
termooksydacyjną niż czyste estry metylowe kwasów tłuszczowych (FAME), otrzymane z oleju rzepakowego (rysunek 6). Zatem FAME, które są obecnie powszechnie stosowanym biokomponentem do oleju napędowego, znacznie szybciej wytrącają osady i pogarszają właściwości fizyko- chemiczne z czasem magazynowania niż bioolej uzyskany z mikroalg. Stabilność biooleju popirolitycznego była jednak znacząco niższa od czystego oleju napędowego (prawie 2,5-krotnie), co można przypisać dużemu udziałowi połączeń nienasyconych.

\section{Podsumowanie}

Podsumowując powyższe rozważania, należy podkreślić, że ustawiczne zwiększanie zapotrzebowania na nośniki energii, w tym paliwa ciekłe, oraz rosnące wymogi normatywne w aspekcie ekoprzyjazności paliw powodują konieczność systematycznego zwiększania udziału energii pochodzącej ze źródeł odnawialnych w ogólnej podaży energii. W obliczu olbrzymiej skali problemu głodu, dotykającego około 13\% populacji ludzkiej, produkcja biopaliw pierwszej generacji budzi coraz większe kontrowersje ze względu na charakter konkurencyjny z rynkiem żywności oraz ogromne zapotrzebowanie na areały pod uprawy surowców do ich produkcji. Niezbędny jest zatem rozwój i przemysłowa implementacja alternatywnych technologii produkcji biopaliw - tzw. paliw drugiej i trzeciej generacji. Przedstawione wyniki badań pozwalają na stwierdzenie, że biomasa mikroalg jest dobrze rokującym surowcem, umożliwiającym produkcję biooleju stanowiącego wartościowy półprodukt nowoczesnych bio- paliw. Poprzez proces pirolizy pozyskano około $30 \%(\mathrm{~m} / \mathrm{m})$ biooleju w odniesieniu do masy surowca, a uzyski poszczególnych grup produktów były uzależnione od warunków procesu konwersji. Badano wpływ warunków procesu konwersji na skład jakościowy produktów. Bioolej popirolityczny z biomasy mikroalg zawiera ogromną ilość związków mających w swych strukturach bardzo różne grupy funkcyjne, determinujące właściwości fizykochemiczne oleju. Otrzymany produkt stanowi wartościową bazę surowcową, zawierającą ogromną liczbę cennych związków chemicznych, które po separacji można wykorzystywać $\mathrm{w}$ różnych gałęziach przemysłu. Należy jednak podkreślić, że ze względu na złożoność składu bezpośrednia aplikacja biooleju do zasilania spalinowych silników tłokowych lub procesów przemysłowych jest niemożliwa. Dlatego też istnieje potrzeba prowadzenia badań w zakresie dodatkowych procesów rafinacyjnych i uszlachetniających biooleje popirolityczne.

Prosimy cytować jako: Nafta-Gaz 2017, nr 9, s. 641-650, DOI: 10.18668/NG.2017.09.03

Artykuł nadesłano do Redakcji 28.06.2017 r. Zatwierdzono do druku 31.07.2017 r.

Artykuł powstał na podstawie prac w ramach grantu nr 15.11.210.411 realizowanego na Wydziale Energetyki i Paliw Akademii Górniczo-Hutniczej im. St. Staszica w Krakowie. Praca wsparta infrastrukturą badawczą Centrum Energetyki AGH.

\section{Literatura}

[1] Brennan L., Owende P.: Biofuels from microalgae - A review of technologies for production, processing and extractions of biofuels and co-products. Renewable and Sustainable Energy Reviews 2010, vol. 14, s. 557-577.

[2] Bridgwater A.V., Peacocke G.V.C.: Fast pyrolysis processes for biomass. Renewable and Sustainable Energy Reviews 2000, vol. 4, s. 1-73.

[3] Brown R.C.: Thermochemical processing of biomass - conversion into fuels, chemicals and power. John Wiley \& Sons 2012.

[4] Canakci M., Sanli H.: Biodiesel production from various feedstocks and their effects on the fuel properties. Journal of Industrial Microbiology and Biotechnology 2008, vol. 35, s. $431-441$.

[5] Du Z., Li Y., Wang X., Wan Y., Chen Q., Wang C., Lin X., Liu Y., Chen P., Ruan R.: Microwave-assisted pyrolysis of microalgae for biofuel production. Bioresource Technology 2011, vol. 102, s. 4890-4896.

[6] Duan P., Jin B., Xu Y., Yang Y., Bai X., Wang F., Zhang L., Miao J.: Thermo-chemical conversion of Chlorella pyrenoidosa to liquid biofuels. Bioresource Technology 2013, vol. 133, s. 197-205.
[7] Grierson S., Strezov V., Ellem G., Mcgregor R., Herbertson J.: Thermal characterisation of microalgae under slow pyrolysis conditions. Journal of Analytical and Applied Pyrolysis 2009, vol. 85, s. 118-123.

[8] Jena U., Das K.C.: Comparative evaluation of thermochemical liquefaction and pyrolysis for bio-oil production from microalgae. Energy \& Fuels 2011, vol. 25, s. 5472-5482.

[9] Liu Y.Q., Lim L.R.X., Wang J., Yan R., Mahakhant A.: Investigation on pyrolysis of microalgae Botryococcus braunii and Hapalosiphon $s p$. Industrial \& Engineering Chemistry Research 2012, vol. 51, s. 10320-10326.

[10] Lopez B.D., Prins W., Ronsse F., Brilman D.W.F.: Hydrothermal liquefaction (HTL) of microalagae for biofuel production: State of the art review and future prospects. Biomass and Bioenergy 2013, vol. 53, s. 113-127.

[11] Maes D., Van Dael M., Vanheusden B., Goovaerts L., Reumerman P., Luzardo N.M., Van Passel S.: Assessment of the sustainability guidelines of EU Renewable Energy Directive: the case of biorefineries. Journal of Cleaner Production 2015, vol. 88, s. 61-70.

[12] Peng W., Wu Q., Tu P.: Effects of temperature and holding time on production of renewable fuels from pyrolysis of Chlorella 
protothecoides. Journal of Applied Phycology 2000, vol. 12, s. $147-152$

[13] Searchinger T., Heimlich R., Houghton R.A., Dong F., Elobeid A., Fabiosa J., Tokgoz S., Hayes D., Yu T-H.: Use of U.S. croplands for biofuels increases greenhouse gases through emissions from land-use change. Science 2008, vol. 319, s. $1238-1240$.

[14] Strona internetowa: http://ec.eurostat.eu/eurostat (dostęp: maj 2017).

[15] Tat M.E., Van Gerpen J.H.: The kinematic viscosity of biodiesel and its blends with diesel fuel. Journal of the American Oil Chemists' Society 1999, vol. 76, s. 1511-1513.

[16] Thangalazhy-Gopakumar S., Adhikari S., Ravidran H., Gupta R.B., Fasina O., Tu M., Fernando S.D.: Physical properties of bio-oil produced at various temperature from pine

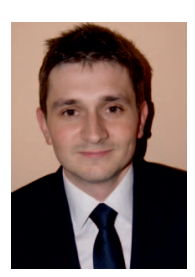

Dr inż. Mariusz WADDRZYK

Adiunkt w Katedrze Technologii Paliw

Wydział Energetyki i Paliw

Akademia Górniczo-Hutnicza

al. A. Mickiewicza 30

30-059 Kraków

E-mail:wadrzyk@agh.edu.pl

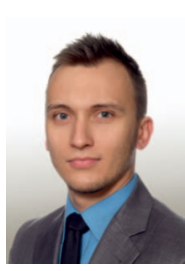

Dr inż. Tadeusz DZIOK

Adiunkt w Katedrze Technologii Paliw

Wydział Energetyki i Paliw

Akademia Górniczo-Hutnicza

al. A. Mickiewicza 30

30-059 Kraków

E-mail: tadeusz.dziok@agh.edu.pl wood using an auger reactor. Bioresource Technology 2010, vol. 101, s. 8389-8395.

[17] The current status of biofuels in the European Union, their environmental impacts and future prospects. EASAC Policy Report 2012, s. 1-47.

[18] Wądrzyk M.: Dobór parametrów procesu hydrotermicznego uptynniania i pirolizy mikroalg dla pozyskania biooleju. Praca doktorska, Wydział Energetyki i Paliw AGH 2015.

[19] Wądrzyk M., Jakóbiec J., Janus R.: Badanie wptywu temperatury procesu pirolizy biomasy mikroalg na sktad chemiczny biooleju popirolitycznego. Przemysł Chemiczny 2014, nr 12, s. 1-5.

[20] Westerhof R.J.M., Brilman D.W.F., van Swaaij W.P.M., Kersten S.R.A.: Effect of temperature in fluidized bed fast pyrolysis of biomass: oil quality assessment in test units. Industrial \& Engineering Chemistry Research 2010, vol. 49, s. 1160-1168.

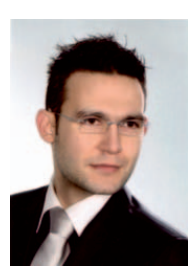

Dr inż. Rafał JANUS

Adiunkt w Katedrze Technologii Paliw

Wydział Energetyki i Paliw

Akademia Górniczo-Hutnicza

al. A. Mickiewicza 30

30-059 Kraków

E-mail:rjanus@agh.edu.pl

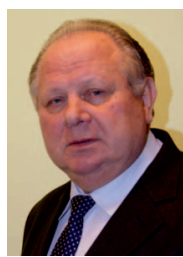

Prof. dr hab. inż. Janusz JAKÓBIEC

Profesor zwyczajny

Wydział Energetyki i Paliw,

Katedra Technologii Paliw

Akademia Górniczo-Hutnicza

al. A. Mickiewicza 30, 30-059 Kraków

E-mail:jjakobie@agh.edu.pl 